\title{
The Solution for Narrow Land Agriculture to Obtain Profit in Deli Tua, Indonesia
}

\author{
Wahyunita Sitinjak \\ Agriculture Faculty, Simalungun University (USI), Simalungun, Indonesia
}

\begin{abstract}
Rural poverty is influenced by the level of education of the head of the family, mastery of the base of the land area, and natural conditions (agricultural land). Likewise, in this study of 'Analysis of the Factors Causing Poor Farmers' Revenues in Deli Tua District', it is assumed that farm household income is influenced by factors of education of the head of household, extent of land tenure, access to financial institutions, existence of alternative business and family dependents. The purpose of this thesis research is; (I) to find out whether the extent of land tenure, education level, number of family dependents, accessibility to financial institutions and the existence of business alternatives affect the income level of farmers, (2) to find out whether there is an influence of land area differences on income levels, (3) find out whether there is an influence of the differences in the status of own land and rent to income level, and (4) to find out the income distribution between farmers who control the 0.5 ha cultivated area and farmers who control the cultivated area greater than 0.5 ha. The research was conducted using descriptive method Primary data was collected by distributing 68 questionnaires in 6 (six) villages and villages in Deli Tua sub-district, Deli Serdang district, namely Deli Tua sub-district, Deli Tua Barat and Deli Tua Timur and Mekar Sari village, Kedai Durian and Suka Makmur.
\end{abstract}

Keywords: narrow land; agriculture; business; profit

\section{Introduction}

Agriculture is a process of producing food, livestock and agro-industrial products. This process is carried out by utilizing natural resources from plants to animals. Utilizing natural resources for agriculture should be accompanied by cultivation. But unfortunately there are many people who only take advantage of the agriculture and do not do any cultivation at all. As a result natural resources will be increasingly depleted only to meet basic human needs alone. The practice of agriculture is also known as "farming", while scientists, inventors and others devoted to improving farming methods and implements are also said to be engaged in agriculture. Subsistence farming, who farms a small area with limited resource inputs, and produces only enough food to meet the needs of his/her family. At the other end is commercial intensive agriculture, including industrial agriculture.Such farming involves large fields and/or numbers of animals, large resource inputs (pesticides, fertilizers, etc.), and a high level of mechanization. These operations generally attempt to maximize financial income from grain, produce, or livestock. Modern agriculture extends well beyond the traditional production of food for humans and animal feeds.

Other agricultural production goods include timber, fertilizers, animal hides, leather, industrial chemicals (starch, sugar, alcohols and resins), fibers (cotton, wool, hemp, silk and flax), fuels (methane from biomass, ethanol, biodiesel), cut flowers, ornamental and nursery plants, tropical fish and birds for the pet trade, and both legal and illegal drugs (biopharmaceuticals, tobacco, marijuana, opium, cocaine). The 20th Century saw massive changes in agricultural practice, particularly in agricultural chemistry. Agricultural chemistry includes the application of chemical fertilizer, chemical insecticides, and chemical fungicides, soil makeup, analysis of agricultural products, and nutritional needs of farm 
animals. Beginning in the Western world, the green revolution spread many of these changes to farms throughout the world, with varying success.Other recent changes in agriculture $\mathrm{i}$ nclude hydroponics, plant breeding, hybridization, gene manipulation, better management of soil nutrients, and improved weed control. Genetic engineering has yielded crops which have capabilities beyond those of naturally occuring plants, such as higher yields and disease resistance. Modified seeds germinate faster, and thus can be grown in an extended growing area. Genetic engineering of plants has proven controversial, particularly in the case of herbicide-resistant plants. As of 2006, an estimated 36 percent of the world's workers are employed in agriculture (down from $42 \%$ in 1996), making it by far the most common occupation. However, the relative significance of farming has dropped steadily since the beginning of industrialization, and in 2006 - for the first time in history - the services sector overtook agriculture as the economic sector employing the most people worldwide.

\subsection{Farming}

\section{Review of Literature}

Farming is a group of activities in cultivation. Farmers are people who do farming such as "rice farmers", "fish farmers" and so on. For those who do farming by cultivating animals, they are called breeders. Agriculture is one of the agribusiness sectors which is considered as an economic activity. In the world of agriculture, the field system is called the most primitive system. In agriculture, the processing of land carried out is very minimum, besides, the level of productivity carried out by farmers also depends on the availability of topsoil on the soil. Farming is growing crops or keeping animals by people for food and raw materials. Farming is a part of agriculture.Agriculture started thousands of years ago, but no one knows for sure how old it is. The development of farming gave rise to the Neolithic Revolution whereby people gave up nomadic hunting and became settlers in what became cities. People probably started agriculture slowly by planting a few crops, but still gathered many foods from the wild. People may have started farming because the weather and soil began to change. Farming can feed many more people than hunter-gatherers can feed on the same amount of land.

\subsection{Agricultural food crops}

Food crops are one example of agriculture that is widely chosen in Indonesia. In our country, many food crops are chosen as population economic activities such as rice, tubers, corn and others. Those who are on dry land, usually choose a tegal system for their yards. This is because water sources are far from the farm location. This system is carried out by those who have long settled in the area. However, the tegal system has a low management level and does not require a large amount of energy. Use of animal services is also rarely needed in this system. Plants chosen as sources of production are plants that are resistant to dry climates.

Rice field system is one of the agricultural businesses that require high cultivation techniques. In the rice field system, there is high biological stability because land and water treatment is involved in this system. No wonder, if the level of soil fertility can be maintained. Rice fields require good irrigation and drainage. Rice fields have a great potential to produce food crops like palawija and paddy.Plantation systems are usually chosen for those who prefer to produce export crops. There are many examples of export material 
products such as tea, chocolate, rubber, coffee and others. Until now the plantation system has continued to grow given the export needs which also require a lot of production goods. Improving Agricultural Products

Not only one or two farmers, but there are many farmers who complain that the results of their agricultural production decline. In this case we need a way to improve the right agricultural products, namely:

\section{Agricultural intensification}

Agricultural intensification is one of the best ways to process agricultural land to increase yield by utilizing various types of facilities. Agricultural intensification was chosen as a way to increase agricultural yields on Java and the island of Bali. This is because, on the island of Java and Bali, agricultural land tends to be narrow.

Agricultural intensification can be done by running a five-farm program that continues with the farming business. The steps that can be taken in increasing agricultural output through sapta farming are:

- Good soil treatment

- Irrigation regularly

- Use of superior seeds

- Perform regular fertilization until it absorbs into the part of the root

- Steps to eradicate pests and diseases in plants

- Processing after harvest

\section{Agricultural extensification}

Agricultural extensification is one way to increase agricultural yields by expanding land. This can be done by opening a forest area, utilizing the area around the swamp, opening bushes, and opening up agricultural land that has not been used. Not only that, but the extension of agriculture can also be done by opening tidal rice fields.

This method of increasing agricultural yields has been chosen and carried out in areas with rare populations. For example, Sumatra and Kalimantan, also Irian Jaya.

\section{Diversification of agriculture}

Agricultural diversification is one type of business carried out by utilizing several types of production. This is done to avoid dependence on any type of plant. In diversifying there are 2 ways you can do that is by increasing the types of agricultural activities. For example, food crop farmers, who also raise livestock such as grouping chickens and fish. The second way is to multiply the types of plants found in one field. An example is by men

For example, food crop farmers, who also raise livestock such as grouping chickens and fish. The second way is to multiply the types of plants found in one field. An example is planting corn and rice in one field.

\section{Mechanization of agriculture}

How to increase agricultural yields is done by utilizing modern agricultural machinery. Agricultural mechanization is mostly applied outside Java, especially in areas that have extensive agricultural land. In the mechanization of agriculture, human and animal power is not the main land processing power.

\section{Agricultural rehabilitation}

The next way to increase agricultural yields is to do agricultural rehabilitation. This business is carried out by improving land, which initially no longer produces production to become productive land. This can be done by replacing plants that no longer produce into the types of plants that produce. 
In developing agriculture in Indonesia, the government does not raise hands but also helps through the following steps:

- Expand and improve the maintenance of extensive irrigation networks throughout Indonesia

- Improve food farming systems by applying various methods such as conducting mass guidance

- Carry out development such as fertilizer plants and insecticide factories as well as pesticides to facilitate agricultural production

In addition, another way to increase agricultural yields is to build a rice mill and mill with a basic price of grain. So that farmers do not feel burdened. Another way is to provide various types of subsidies and capital intensive for farmers so that their capacity in agricultural production increases. It also forms farmer groups as well as KUD in all corners of the village. This is done to increase people's motivation and provide solutions for those who are facing difficulties in terms of production.

\section{Examples of Agricultural Production}

There are several examples of plants commonly chosen to be cultivated as production plants in agriculture such as:

1. Tea

Tea is one type of plant that is used as a mixture in drinks. Tea can grow and develop as long as the following conditions are met:

- Planted in mountainous areas with cool air.

- Good elevation ranging from 200 to 2000 meters above sea level. The higher the tea planted in an area, the better the quality of tea.

- Get enough sunlight. (read: function of sunlight for plants)

- Plants used are fertile with a lot of rainfall.

Areas that have many tea plantations are West Java, precisely in Priangan, West Sumatra, Jambi, South Sumatra, Pematang Siantar and Bengkulu area. Domestic tea is generally exported to America, the Netherlands, Germany, Australia and Singapore.

2. Sugarcane

The most cultivated plants in Indonesia are sugarcane. Sugar cane produces sugar which we use every day for cooking and making drinks. Sugar cane is considered a grass plant that stands strong and strong. Sugar cane can grow well if the following conditions are met:

- Planted in dry and hot climates but humid with temperatures between $25^{\circ} \mathrm{C}-28^{\circ} \mathrm{C}$

- Areas with rainfall less than $100 \mathrm{~mm}$ per year

In order for sugar cane to produce high sugar levels, you are expected to pay attention to the time of planting. When young, this plant needs a lot of water to live. When sugar cane starts to get old, the water needs are no longer too necessary. The sugar cane producing regions in Indonesia include Java, Lampung, Nusa Tenggara and South Sumatra.

3. Coffee

One more type of plant that is widely used as a beverage is coffee. This type of plant can thrive if planted in mountainous areas. The requirements for growing coffee include:

- Fertile land

- Cool surrounding air

- Grows at an altitude of 10 to 1500 meters above sea level

- Need lots of sun and rain

- Can also grow in the lowlands 
In Indonesia, coffee began to be planted on the island of Java in 1696 with Arabica coffee originating from East Africa or precisely in Ethiopia. The next coffee known to enter Indonesia is the type of Liberika coffee originating from West Africa. Because this type of coffee is susceptible to disease, the development of other types of coffee, namely the type of robusta coffee is carried out. Robusta coffee is a type of coffee originating in West Africa.

Robusta coffee is found in Java and Sumatra. This type of coffee is suitable to be planted on land with a height of 10 to 800 meters above sea level. Planting crops especially the type of production plant should be done according to the type of plant so that it is tanned

\section{Discussion}

Based on data from the Central Statistics Agency (BPS), out of a total of 26.14 million farmer households, 56.12 percent are smallholders who do not own land or ownership of land is just under 0.3 hectares. In addressing the problem of the narrowness of agricultural land, the government pursues efforts to intensify and intensify. Extensification is an effort to increase agricultural output by expanding new agricultural land, for example by clearing forests and shrubs, areas around swamps, and agricultural areas that have not been utilized. However, the extension carried out by opening new land outside Java has many obstacles. One of the obstacles faced is the incompatibility of the new land for agricultural purposes. Intensification is considered to be an absolute effort that must be made to maintain agricultural production. Agricultural intensification is an effort to increase agricultural yields by optimizing existing agricultural land. Agricultural intensification was carried out with the Panca Usaha Tani program, which was then followed by the Sapta Usaha Tani program.

The sapta farming in the field of agriculture includes the following activities:

\section{Selection of Superior Seeds}

The initial step of Sapta farming is the selection of superior seeds. This is the most important thing. Superior seeds are seeds that are obtained from genetic engineering, sorting, and long grading to produce good quality seeds and resistant to pests and diseases. In addition to selecting quality seeds, adjusting the seedlings to the planting season also needs to be considered. The initial stage of farming is very decisive but often overlooked. Particularly the adaptation of seeds is suitable in the first planting or period, the first dry season or the second period, or the second or third dry season.

\section{Planting Season or first period}

Done from November to December by planting seeds of any variety. This is because seeds can grow and produce with good productivity. But keep in mind that in the range of this month is the rainy season so choosing seeds with varieties that have sturdy stems will be better.

\section{First or second dry season}

In sapta farming activities, especially the selection and adjustment of seeds in the second period, it is necessary to consider the selection of seeds that are resistant to pests and diseases. In the second period around March to April is the dry season where rice will be easily attacked by pests and diseases. Therefore, despite low productivity, still choose varieties that are resistant to pests and diseases.

\section{Second or third period}

In July to August is the third period. Almost all seeds with any variety can survive this season. So that it can be said this season is the season of glory of farmers. 
Good Soil Processing

A good land or soil condition is land that provides various kinds of complete nutrients needed by plants.

In addition to these conditions, the soil must contain organic and inorganic substances, water, and air. Therefore, to assist the ability of the land to obtain this, Sapta is required to undertake farming efforts, namely good soil management. In carrying out optimal tillage in sapta is done by plowing the land or soil $30 \mathrm{~cm}$ deep evenly. Piracy is done until the surface is completely evenly distributed so that when planting there is no soil surface that is flooded by water. This is done to improve soil structure. Loose soil due to processing has enough cavities for storing water and air. Soil microorganisms become very helpful in the process of decomposition of minerals and soil organic matter.

\section{Appropriate Fertilization}

The process of fertilizing in farming farming is a business that aims to replace nutrients lost from the soil due to harvesting, volatilization, washing, fixation and so on.

Good fertilization is done in a balanced manner and in the right time frame. The use of chemical fertilizers is highly recommended for following doses and not too much because it can change the composition of soil nutrients and damage the womb. And the most important thing is to multiply the use of natural fertilizers as soil rehabilitation.

\section{Disease Control}

In the fourth stage in Sapta farming, namely controlling pests and diseases there are various ways. There are mechanical controls, environmental or ecological and chemical sanitation arrangements. Mechanical control is carried out by capturing pests directly.

This condition can be done if the pest population is not too much. Another step is the regulation of environmental sanitation. Good environmental sanitation/ hygiene arrangements can reduce the likelihood of attacking pests. The final step is chemical control of pests.

\section{Conclusion}

Poverty is one of the main problems faced by developing countries. The economic crisis in Asian countries at the end of the 90s has increasingly added to the number of poor families in developing countries, including Indonesia. Various studies show that the causes of poverty, especially in rural areas, are education and land tenure, so there is also a significant (significant) relationship between rural poverty and land management. Based on the results of the above research, rural poverty is influenced by the level of education of the head of the family, mastery of the base of the land area, and natural conditions (agricultural land). Likewise, in this study of 'Analysis of the Factors Causing Poor Farmers' Revenues in Deli Tua District', it is assumed that farm household income is influenced by factors of education of the head of household, extent of land tenure, access to financial institutions, existence of alternative business and family dependents. The purpose of this thesis research is; (I) to find out whether the extent of land tenure, education level, number of family dependents, accessibility to financial institutions and the existence of business alternatives affect the income level of farmers, (2) to find out whether there is an influence of land area differences on income levels, (3) find out whether there is an influence of the differences in the status of own land and rent to income level, and (4) to find out the income distribution between farmers who control the 0.5 ha cultivated area and farmers who control the cultivated area 
greater than 0.5 ha. The research was conducted using descriptive method Primary data was collected by distributing 68 questionnaires in 6 (six) villages and villages in Deli Tua subdistrict, Deli Serdang district, namely Deli Tua sub-district, Deli Tua Barat and Deli Tua Timur and Mekar Sari village, Kedai Durian and Suka Makmur.

\section{References}

Abdul Latief, 2005. Permasalahan Dalam Penerapan Sistem Pengendalian Hama Terpadu Untuk Pengelolaan Penyakit Tumbuhan di Indonesia, Fakultas Pertanian Universitas Brawijaya

Aceh Timur Dalam Angka 2013. Laporan Perkebunan Rakyat, BPS Kabupaten Aceh Timur, Ance Gunarsih K, 2004. Klimatologi, Pengaruh Iklim Terhadap Tanah dan Temperatur, Bina Aksara, Jakarta.

BPK Kecamatan Sungai Raya, 2013. Laporan Perkebunan Rakyat, Kecamatan Sungai Raya. Darianto, 2007. Sistem Intensifikasi Pertanian, Warta Pertanian Institut Pertanian Bogor (IPB), Bogor.

Dwi Astuti, 2013. Analisis Regresi Linear dan Berganda. Makalah Statistika, FE-Univ. Diponegoro, Semarang.

Hanum, 2008. Teknik Budidaya Tanaman, Jilid 3, Departemen Pendidikan Nasional, Jakarta. Kiswanto, 2008. Teknologi Budidaya Kelapa Sawit, Badan Penelitian dan Pengembangan Teknologi Pertanian, Lampung.

Nazir, 2005. Metode Penelitian, Ghalia Indonesia, Jakarta.

Rini W, 2004. Petunjuk Penggunaan Pestisida, Penebar Swadaya, Jakarta.

Rismawan, 2010. Budidaya dan Pengelolaan Kebun Kelapa Sawit, Penebar Swadaya, Jakarta.

Soewardi H, 1996. Respon Masyarakat Desa Terhadap Modernisasi Produksi Pertanian, Fakultas Pertanian Universitas Padjajaran.

Sudjana, 2005. Metode Statistik, CV. Tarsito, Bandung.

Sutopo, 2011. Pestisida dan Perlindungan Tanaman, Warta Pertanian, Institut Pertanian Bogor - Bogor.

Su'ud, 1996. Mengenal Pembangunan Pertanian dan Perkaitannya, Universitas Syiah Kuala, Darussalam-Banda Aceh.

Artha, 2008. Pola Intensifikasi Peningkatan Produksi Pertanian, Buletin Pertanian, Jakarta 